\title{
Construction of Enterococcus faecalis pAD1 Miniplasmids: Identification of a Minimal Pheromone Response Regulatory Region and Evaluation of a Novel Pheromone-Dependent Growth Inhibition
}

\author{
KeITH E. Weaver ${ }^{1}$ AND DON B. Clewell ${ }^{2}$ \\ Departments of Oral Biology and Microbiology/Immunology, Schools of Dentistry and Medicine, \\ The University of Michigan, Ann Arbor, Michigan 48109-0402
}

Received May 18, 1989; revised August 18, 1989

\begin{abstract}
Several pAD1 miniplasmids were constructed that consisted of all or a portion of the pAD1 $E c o$ RI B fragment with pheromone-inducible "E region" lac $Z$ transcriptional fusions. Miniplasmids containing the entire EcoRI B fragment (the "E miniplasmids") were found to regulate LacZ expression normally, indicating that sufficient information is present on this fragment to regulate a pheromone response. These plasmids also encoded normal replication functions. The $\mathrm{E}$ miniplasmids were further reduced by deleting a $\mathrm{KpnI}$ fragment. These " $\mathrm{K}$ miniplasmids" were able to perform most of the functions central to a pheromone response but failed to induce the fused transcripts to levels observed in the parental plasmids. This defect was found to be due to a pheromone-dependent growth inhibition of cells containing the $\mathrm{K}$ miniplasmids. Evidence indicated that this inhibition was due to transcriptional readthrough beyond the lac $Z$ gene and into the putative replication region of the plasmid. Possible mechanisms of this inhibition as well as its potential usefulness in further examining the characteristics of the pheromone response are discussed. (c) 1989 Academic Press, Inc
\end{abstract}

Conjugative transfer of a group of plasmids found in the opportunistic pathogen Enterococcus faecalis is induced by small, hydrophobic peptide pheromones (Dunny et al., 1978; Mori et al., 1984, 1988; Suzuki et al., 1984). Each pheromone is specific for a particular plasmid species and is produced only by cells which do not contain the related plasmid (Dunny et al., 1979). Potential donors respond to pheromone by producing a proteinaceous adhesion, called "aggregation substance," which appears on the surface of induced donor cells (Yagi et al., 1983). Aggregation substance facilitates the formation of maling aggregates by binding to a "binding substance" present on the surface of recipient cells. Since plasmidcontaining cells also express binding substance, self-aggregation can be induced by exposure to pheromone. Induction involves synthesis of a number of surface proteins, at least some of which are likely components of aggregation substance (Ehrenfeld et al., 1986;

\footnotetext{
${ }^{1}$ Present addrcss: Department of Microbiology, University of South Dakota, Vermillion, SD 57069.

${ }^{2}$ To whom correspondence should be addressed.
}

Tortorello and Dunny, 1985). Expression of an inducible surface (entry) exclusion has also been associated with one of these proteins in the plasmid pCF10 (Dunny et al., 1985). In addition, functions necessary for transfer of the plasmid itself appear to be inducible (Clewell and Brown, 1980). Thus, when cells containing two different pheromone plasmids are induced by pheromone specific for only one of the plasmids, productive mating aggregates are formed but transfer of only the specifically related plasmid is induced (Ehrenfeld et al., 1986). Once the plasmid has been transferred to the recipient, the production of pheromone activity specific for that plasmid is shut down. Pheromones specific for other plasmids not present in the transconjugant continue to be produced. In addition, transconjugants begin to produce a small peptide which competitively inhibits the action of the pheromone specific for that plasmid (Ike et al., 1983; Mori et al., 1986). Therefore, at least four basic conjugation-related functions must be determined by the plasmid DNA: (i) the detection and transduction of the pheromone signal; (ii) the 
synthesis and/or regulation of the aggregation and transfer functions; (iii) the specific shutdown of endogenous pheromone activity; and (iv) the production of inhibitor.

Plasmid pAD1 ( $\approx 60 \mathrm{~kb}$ ) encodes a response to the sex pheromone CAD1. It also encodes a hemolysin-bacteriocin (Tomich et al., 1979; Clewell et al., 1982) as well as resistance to ultraviolet light (Clewell et al., 1986). The hemolysin-bacteriocin has been implicated as a virulence factor in E. faecalis (Ike et al., 1984, 1987). Previous work with this plasmid defined a region of approximately $31 \mathrm{~kb}$ (Fig. 1) required for a normal pheromone response (Ehrenfeld and Clewell, 1987). For simplicity, determinants within this region can be catagorized into three broad groups: (i) those affecting plasmid transfer but not aggregation or inducible surface protein production (comprising the previously defined $\mathrm{G}$ and $\mathrm{H}$ regions); (ii) those affecting aggregation and/or inducible surface protein production but not transfer if cells are artificially "aggregated" by pressing them together on a solid surface (comprising the previously defined and recently extended $F$ region); and (iii) those affecting both aggregation and transfer (Fig. 1). This latter group represents a cluster of determinants (traA, $\operatorname{tr} a B$, and the $\mathrm{E}$ and $\mathrm{C}$ regions) located near one end of the $31-\mathrm{kb}$ region. These genes are essential for the normal regulation of the pheromone response. The $\mathrm{E}$ region is believed to encode a positive regulator since mutations within this region result in an inability of plasmid-containing cells to aggregate or transfer the plasmid in response to pheromone (Ehrenfeld and Clewell, 1987). In addition, production of $\beta$-galactosidase from lac $Z$ fusions within this region, constructed using $\operatorname{Tn} 917-$ lac (Perkins and Youngman, 1986), is exquisitely sensitive to the presence of pheromone (Weaver and Clewell, 1988). The traA and $\operatorname{tra} B$ genes appear to be negative regulators of the pheromone response, as mutations within

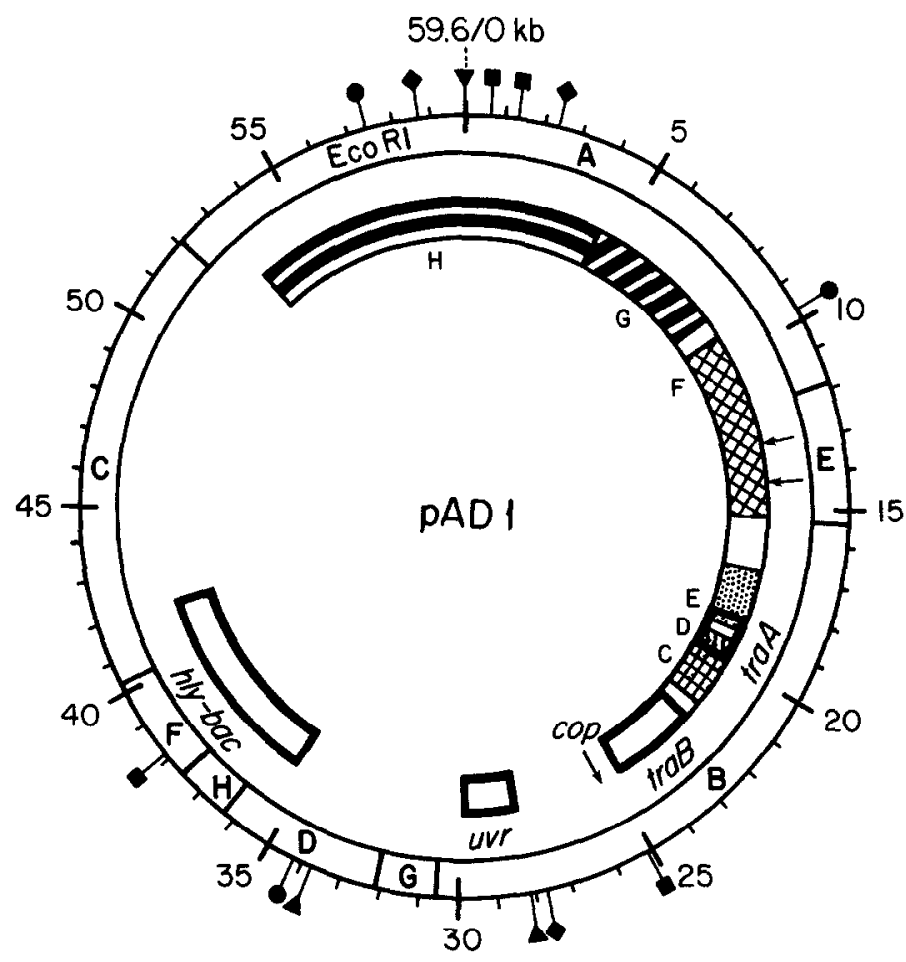

FIG. 1. Physical and functional map of pADI. Regions important for transfer are indicated as shaded or open boxes on the interior of the map and labeled $\operatorname{traA}, \operatorname{traB}$, and $\mathrm{C}$ through $\mathrm{H}$. Regions $h l y-b a c, u v r$, and cop represent genes for hemolysin-bacteriocin, uv resistance determinants, and copy number control, respectively. EcoRI fragments are labeled within the outer circle. Other restriction sites are ( $\nabla), S a l l ;(\square)$ BamHI; (†) KpnI; and (๑) PstI. 
these genes result in constitutive aggregation and rapid transfer of plasmid DNA in matings too short to allow normal pheromone induction (Ike and Clewell, 1984). In addition, abnormalities in the expression of transfer functions and inducible surface proteins observed in some traA mutants suggest that the product of this gene is also required for signal transduction (Weaver and Clewell, 1988). The function of the $\mathrm{C}$ region has yet to be determined, but mutations within this region result in an increased production of $\mathrm{iADl}$ and a decreased sensitivity to pheromone (Ehrenfeld and Clewell, 1987). A subset of mutants within the $C$ region also results in "semiconstitutive" aggregation and transfer (Weaver and Clewell, 1988). Finally, a $2.5-\mathrm{kb}$ deletion within this cluster of genes, removing a portion of $\operatorname{traB}$ and most of the $C$ region, results in the inability of the plasmid to shut down pheromone production (Weaver and Clewcll, 1988; K. E. Weaver, unpublished results). Therefore, genes present within this regulatory cluster are implicated in each of the four expected plasmidencoded functions mentioned above.

To determine if the genes within the regulatory cluster are sufficient for the regulation of the pheromone response and to facilitate further investigations on the interactions of the regulatory factors, we have constructed "miniplasmids" consisting of all or a portion of the EcoRI B fragment of pAD1. Evidence presented in this report indicates that all genetic information necessary to regulate pheromone-inducible genes, as well as determinants required for replication, are present on this fragment. In addition, we report the construction of a miniplasmid derivative which resulted in pheromone-dependent growth inhibition of plasmid-containing cells. Possible mechanisms of this unique observation and its implications to $\mathrm{pAD} 1$ replication and the pheromone response are discussed.

\section{MATERIALS AND METHODS}

Bacterial strains and plasmids. Strains and plasmids used and their relevant characteristics are shown in Table 1. Except where noted plasmid characteristics were determined in an
E. faecalis OGIX background. Plasmids used or constructed in this investigation are shown in Table 1.

Media and reagents. All strains were grown in Antibiotic Medium No. 3 (Difco Laboratories, Detroit, MI) for ethidium bromide$\mathrm{CsCl}$ gradient preparation of plasmid DNA and Todd-Hewitt broth (THB) ${ }^{3}$ (Difco) for rapid plasmid isolation. All other experiments were conducted in N2GT medium (Nutrient Broth No. 2 (Oxoid Ltd., London, UK) supplemented with $0.1 \mathrm{M}$ Tris buffer (pH 7.5) and $0.2 \%$ glucose). Solid medium was prepared by adding agar (1.8\%) (Difco); and hemolysis was detected, when necessary, on THB plates containing 4\% horse blood (Colorado Serum Co., Denver, $\mathrm{CO}$ ). Cultures were incubated at $37^{\circ} \mathrm{C}$. Where appropriate, the following antibiotics were added at the indicated concentrations: streptomycin, $1 \mathrm{mg} / \mathrm{ml}$; fusidic acid, $25 \mu \mathrm{g} / \mathrm{ml}$; rifampin, $25 \mu \mathrm{g} / \mathrm{ml}$; crythromycin, $10 \mu \mathrm{g} / \mathrm{ml}$; tetracycline, $10 \mu \mathrm{g} / \mathrm{ml}$. Other antibiotic concentrations are noted when appropriate.

Construction and physical analysis of pADI miniplasmids. In order to isolate a functional miniplasmid two requirements must be met: (i) the plasmid fragment selected must contain sufficient information for stable replication and inheritance; and (ii) the plasmid fragment must contain a selectable marker. In addition, since our intention was to determine the ability of regulatory genes on the miniplasmid to properly direct a pheromone response, some means of measuring that response was also required. Isolation of a $\mathrm{Tn} 917$ insertion located near the $t r a B$ gene on the pAD 1 EcoRI B fragment that resulted in a fivefold increase in plasmid copy number was previously reported (lke and Clewell, 1984; see also Fig. 2), indicating that pAD1 replication functions might be encoded on this fragment. Inducible lac $Z$ fusions, such as Tn917-lac inserts NRI1 and NR5 (Weaver and Clewell, 1988), within this fragment would provide both the antibiotic selection and a method for quantifying the pheromone response. Therefore, it was con-

\footnotetext{
${ }^{3}$ Abbreviations used: THB, Todd-Hewitt broth; MU, Miller unit.
} 
TABLE 1

E. faecalis STRaINS AND PLASMIDS

\begin{tabular}{|c|c|c|}
\hline Strain or plasmid & Relevant phenotype ${ }^{a}$ & Reference \\
\hline \multicolumn{3}{|l|}{ Strains } \\
\hline $\mathrm{OC} 1 \mathrm{X}$ & str gel & (Ike et al., 1983) \\
\hline FA2-2 & rif fus & (Clewell et al., 1982) \\
\hline DS16 & tet erm & (Tomich et al., 1979) \\
\hline CG110 & $t e t$, high frequency donor of $\operatorname{Tn} 916$ & (Gawron-Burke and Clewell, 1982) \\
\hline \multicolumn{3}{|l|}{ Plasmids } \\
\hline pADI & Hemolysin-bacteriocin & (Tomich et al., 1979) \\
\hline pAM2005A & $\begin{array}{l}\text { pAD1 derivative containing the NR5 } \\
\text { pheromone-inducible } \text { lac } Z \text { fusion, } \\
\text { agg-, } \mathrm{tf}^{-} \text {, isp }\end{array}$ & (Weaver and Clewell, 1988) \\
\hline pAM2005E & Miniplasmid derived from pAM2005A & This report, see Fig. 2 \\
\hline pAM2005K & $\begin{array}{l}\text { Miniplasmid derived from pAM } 2005 \mathrm{E} \text {, } \\
\text { pheromone-inhibited growth }\end{array}$ & This report, see Fig. 2 \\
\hline pAM2005KR & $\begin{array}{l}\text { Spontaneous pheromone-resistant } \\
\text { derivative of pAM } 2005 \mathrm{~K}\end{array}$ & This report \\
\hline pAM2516KT & $\begin{array}{l}\text { Tn916-derived pheromone-resistant } \\
\text { derivative of pAM2005K (KT16 } \\
\text { insert) }\end{array}$ & This report, see Fig. 2 \\
\hline pAM2524KT & $\begin{array}{l}\text { Tn916-derived pheromone-resistant } \\
\text { derivative of pAM2005K (KT24 } \\
\text { insert) }\end{array}$ & This report, see Fig. 2 \\
\hline pAM2011A & $\begin{array}{l}\text { pAD1 derivative containing the NR11 } \\
\text { pheromone-inducible lac } Z \text { fusion, } \\
\text { agg; } \mathrm{tf}^{\prime} \text {, isp }\end{array}$ & (Weaver and Clewell, 1988) \\
\hline pAM2011E & Miniplasmid derived from pAM2011A & This report, see Fig. 2 \\
\hline pAM $2011 \mathrm{~K}$ & $\begin{array}{l}\text { Miniplasmid derived from pAM2011E, } \\
\text { pheromone-inhibited growth }\end{array}$ & This report, see Fig. 2 \\
\hline pAM211 & $\begin{array}{l}\text { pADI ::Tn916 EcoRI F fragment } \\
\text { insert nonhemolytic }\end{array}$ & (Gawron-Burke and Clewell, 1982) \\
\hline
\end{tabular}

${ }^{a}$ agg, aggregation; $\mathrm{tf}$, transfer; isp, inducible surface proteins.

sidered possible that miniplasmids could be constructed from the $E c o$ RI B fragment of plasmids containing one of these inserts.

In order to construct these derivatives, plasmids pAM2005A and pAM2011A (pAD1 derivatives containing the NR5 and NR11 inserts, respectively) were purified by ethidium bromide- $\mathrm{CsCl}$ ultracentrifugation as previously described (Clewell et al., 1974). Approximately $1 \mu \mathrm{g}$ of DNA was digested with $E c o$ RI, precipitated, and religated with $\mathrm{T} 4$ DNA ligase. Religated DNA was then used to transform OG1X protoplasts as previously described (Wirth et al., 1986). Transformants were selected on media supplemented with 2 $\mu \mathrm{g}$ of erythromycin per milliliter. Routine screening of plasmid DNA from transformants was carried out using the small-scale alkaline lysis procedure previously described (Weaver and Clewell, 1988). Plasmid DNA was analyzcd by digestion with various restriction enzymes and electrophoretic separation of restriction fragments on $0.8 \%$ agarose. All restriction enzymes and T4 DNA ligase were obtained from Bethesda Research Laboratories, Inc. (Gaithersburg, MD) and reactions carried out in the buffers provided under the conditions recommended. These derivatives, the $\mathrm{E}$ miniplasmids, were designated pAM2005E and pAM2011E to indicate that they consisted of the entire EcoRI B fragments of their respective parental plasmids (Fig. 2).

To further reduce the size of the miniplasmids a similar isolation procedure was carried 
out with Kpnl-cleaved pAM2005E and pAM2011E. KpnI sites are located just outside of the plasmid-encoded $u v r$ gene and just downstream of the $\operatorname{Tn} 917 \mathrm{erm}$ gene (Shaw and Clewell, 1985). Therefore, such constructs would not be expected to disturb the antibiotic resistance or lac $Z$ determinants. These derivatives, the $\mathrm{K}$ miniplasmids, were mapped and designated pAM2005K and pAM2011K to indicate that they consisted of the KpnI fragment of their respective parental plasmids (see Fig. 2).

Determination of plasmid copy number, incompatibility, and stability. The copy number of pAM2005A, its miniplasmid derivatives, and pAM $201 \mathrm{KK}$ were determined using $\left[{ }^{3} \mathrm{H}\right]$ thymidine-labeled cultures as previously described (Clewell et al., 1974). To determine plasmid incompatibility, pAM211 was transferred by filter mating (Clewell et al., 1985) into OGIX strains carrying the plasmid to be tested. Transconjugants were selected on tetracycline-containing medium to select for the incoming plasmid and then screened for maintenance of the resident plasmid on erythromycin-containing plates. The rate of plasmid loss (i.e., plasmid stability) was determined after cells containing the plasmid were grown from single colony inoculum overnight in selective medium. The cells were washed once and then diluted in fresh nonselective medium. The culture was maintained in log phase by periodic dilution for at least 100 generations or until $<1 \%$ of colony isolates contained the plasmid. Samples were taken periodically and screened for the percentage of plasmid-containing cells based on the retention of the erm determinant. After 100 generations, any remaining erythromycin-resistant colonies were screened for expected plasmid-determined characteristics (e.g., pheromone-dependent growth inhibition or pheromone induction of the $\operatorname{lac} Z$ fusion) to ensure that transposition of $\mathrm{Tn} 917$ or plasmid mutation had not occurred.

Pheromone assays. The concentration of cAD1 was determined by the microtiter assay method described previously (Dunny et al., 1979). The cADl titer was defined as the highest dilution of culture filtrate which induced aggregate formation in responder cells. The inhibitor, iAD1, titer was determined by diluting a culture filtrate from plasmid-free cells through culture filtrates to be tested in the microtiter assay (Ike et al., 1983). The inhibitor titer was represented as the pheromone titer in the absence of inhibitor divided by the titer in its presence. Because iAD1 production is very low in an E. faecalis OG1X background, all plasmids were transferred to E. faecalis strain FA2-2 to ensure that iAD1 production was normal. In the case of nonconjugative pAD1 derivatives and miniplasmids, this was accomplished by performing triparental matings between the plasmid-containing strain and FA2-2, using OG1X(pAD1) as the helper. Transconjugants were selected on plates containing fusidic acid, rifampin, and erythromycin and then screened for pheromoneinduced production of $\beta$-galactosidase or pheromone inhibition. In addition, miniplasmid-bearing transconjugants were checked for hemolysin production, transmissibility, and plasmid content to ensure that no pADl copies coexisted in the cell.

Pheromone response and pheromone-dependent growth inhibition. To test the pheromone responsiveness of cells containing miniplasmids and their parental plasmids, 1:10 dilutions were made from an overnight culture of the strain to be tested and grown for 30 min. Cultures were then induced with $0,2.5$, $5,10,20$, and $40 \mathrm{ng} / \mathrm{ml}$ of synthetic cAD1 (custom made by Milligen Inc., Waterton, MA) for $90 \mathrm{~min}$. Cell density was determined using a Spectronic 21 colorimeter (Bausch \& Lomb, Inc., Rochester, NY) at a wavelength of $600 \mathrm{~nm}$. Cells were harvested, toluenized, and assayed for $\beta$-galactosidase activity as previously described (Weaver and Clewell, 1988). Assays were conducted with $40 \mu \mathrm{l}$ of sample for $30 \mathrm{~min}$. Activities are expressed in Miller units (MU; Miller, 1972). Plasmid-containing strains were routinely checked for pheromonedependent growth inhibition by exposing early log phase cultures to $20-40 \mathrm{ng}$ of cAD1 per milliliter and following growth at OD 600 as above. Specific conditions of various inhibition experiments are described in the text. 

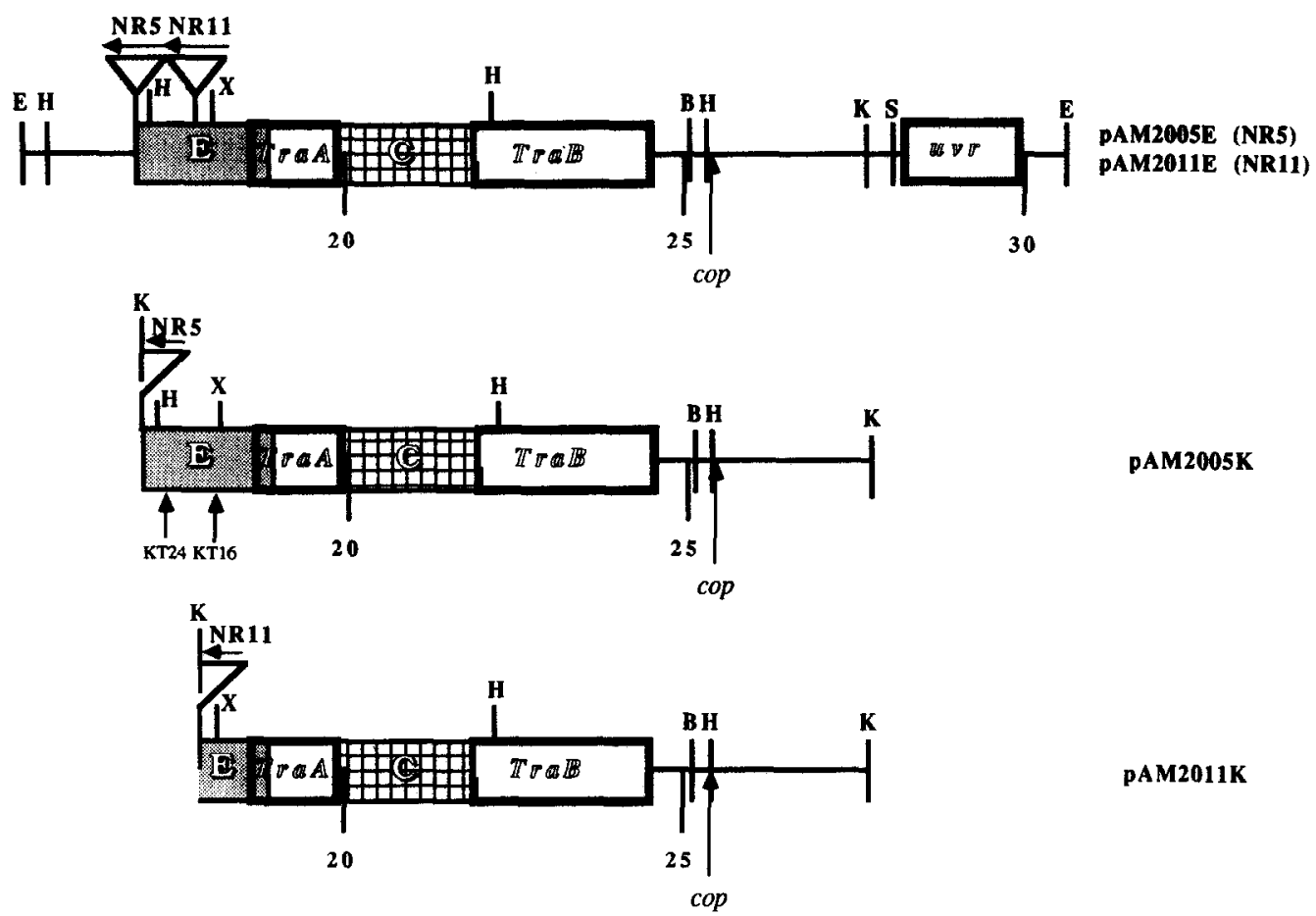

pAM2005K

pAM2011K

FIG. 2. Plasmid maps of pAD1 miniplasmids. All four plasmids consist of portions of the pAD1 EcoRI $B$ fragment and each contains an inducible lacZ fusion, NR5 or NR11, indicated by the insertion triangle. pAM2005E and pAM2011E differ only in the site of the Tn917-lac insertion, NR5 and NR11, respectively. The regions designated $\operatorname{tr} A A, \operatorname{tr} a B, \mathrm{C}$, and $\mathrm{E}$ have previously been shown to be important for pheromone regulation. The $u v r$ gene is required for the plasmid-encoded uv resistance. Restriction sites are designated above the map and kb markers below. Restriction sites mapped are E, EcoRI; H, HindIII; X, XbaI; B, BamHI; K, KpnI; S, Sall. Tn917-lac contains several HindIII and Sall sites that are not shown and a single $K p n I$ site which was used in the construction of pAM2005K and pAM2011K. Also shown on the pAM2005K map are the sites of two Tn916 inserts, KT16 and KT24, which relieve the pheromone-dependent growth inhibition. The deletion present in pAM2005KR is located between the HindIII and the KpnI sites on the far right end of pAM2005K. The site marked cop is a formerly mapped locus at which a Tn 917 insert results in a fivefold increase in plasmid copy number.

Mutagenesis and selection of pheromone resistant mutants of pAM2005K. Spontaneous pheromone-resistant mutants of pAM $2005 \mathrm{~K}$ were selected simply by streaking single colonies of OG1X (pAM2005K) on plates containing 20-40 $\mathrm{ng}$ of $\mathrm{CAD} 1$ and $100 \mu \mathrm{g}$ of 5bromo-4-chloro-3-indolyl- $\beta$-D-galactoside (Sigma Chemical Co., St. Louis, MO) per milliliter. Colonies that grew faster than the background and produced a blue pigment, indicating induction of the $\mathrm{E}$ region $l a c Z$ fusion, were selected for further analysis. $\operatorname{Tn} 916$ transposon mutants were selected following an overnight filter mating of the plasmid-containing strain with CG110. Transconjugants were selected on tetracycline- and strepto- mycin-containing plates supplemented with 20-40 ng of cAD1 per milliliter. Colonies growing faster than background were selected and purified for further characterization.

\section{RESULTS}

\section{Replication and Pheromone Induction Characteristics of pADI Miniplasmids}

Miniplasmids were constructed from the pAD1::Tn917-lac derivatives pAM2005A and pAM2011A as described under Materials and Methods. Physical and functional maps of the miniplasmids are shown in Fig. 2. All miniplasmid-containing strains failed to produce cAD1 and excreted normal levels of iAD1. 


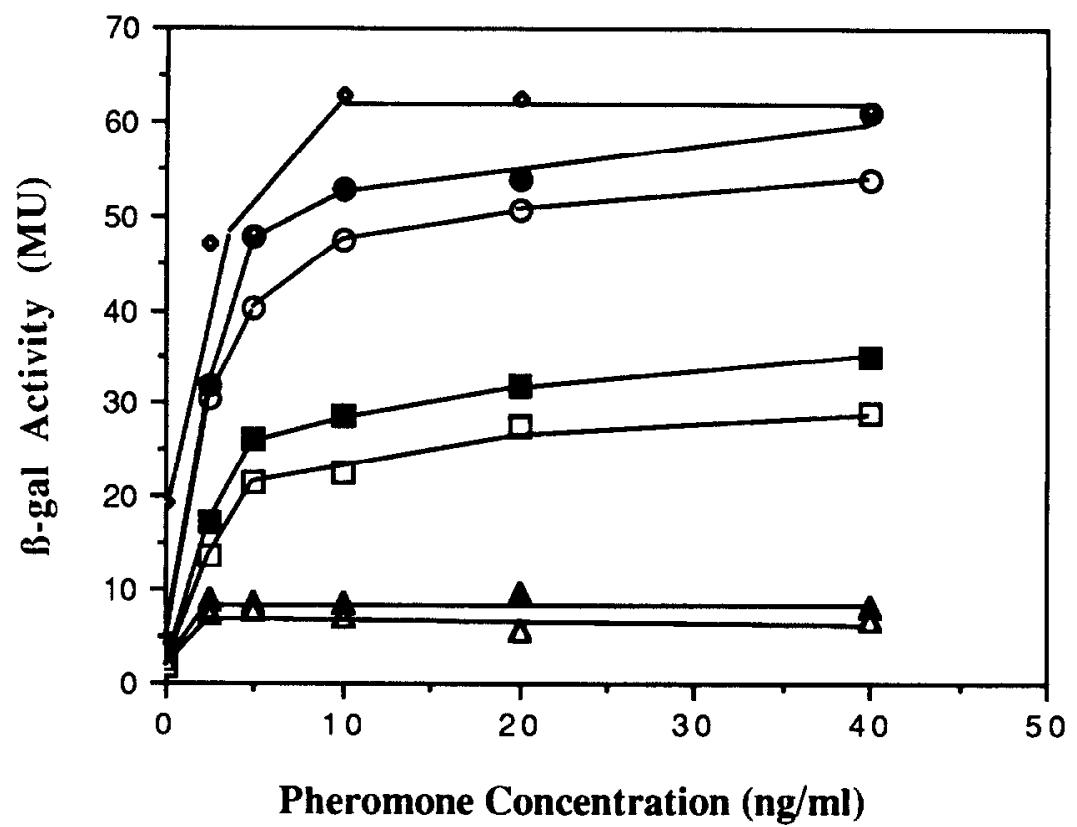

FIG. 3. Pheromone response of miniplasmids and their parental plasmids. OGIX strains containing the various plasmids were cultured and induced as described under Materials and Methods. $\beta$-Galactosidase activity is expressed in Miller units, a unit of measure normalized to culture optical density. Each line is an average of three independently conducted experiments. Symbols: (O) pAM2005A; (๑) pAM2005E; (A) pAM2005K; $(\diamond)$ pAM2005KR; ( $\square)$ pAM2011A; (a) pAM2011E; $(\triangle)$ pAM2011K.

Comparison of the parental pAD1 ::Tn917lac plasmid, pAM2005A, with its two miniplasmid derivatives, pAM2005E and pAM2005K, revealed that maintenance was near normal in all cases. Copy numbers of all three plasmids were two to four per chromosome equivalent. In addition, no significant difference in expression of incompatibility was observed between the miniplasmids and pAM2005A following uptake and selection for pAM211 (see Materials and Methods). In all cases, loss of the unselected erm determinant was greater than $90 \%$. Uptake frequencies of pAM211 were one to two orders of magnitude higher when the recipient contained one of the miniplasmids, compared to pAM2005Acontaining recipients $\left(\approx 10^{-4}\right.$ vs $10^{-5}$ per donor cell). The presence of an as yet unidentified surface exclusion function on pAM2005A that is absent on the miniplasmids could account for this difference. Similar copy number and incompatability characteristics were observed for the smaller miniplasmid, pAM2011K.

The pAM2005E derivative was slightly less stable than its parent, pAM2005A. Thus,
pAM2005E was lost at $\approx 0.1 \%$ per generation in the absence of selection while no loss of pAM2005A was observed. This may be less due to deletion of maintenance functions than to the loss of the hemolysin-bacteriocin determinant from the miniplasmid. The bacteriocin might be expected to quickly kill any plasmid-free segregant, resulting in an apparent increase in plasmid stability. Stability of pAM2005K was highly variable, ranging from greater than $99 \%$ plasmid loss within 50 generations to less than $5 \%$ loss over 100 generations. In one experiment the plasmid was maintained in $90 \%$ of cells over 40 generations and then was lost from $>99 \%$ of cells over the next 30 generations. In all cases, erythromycinresistant strains remaining near the end of the experiment were indistinguishable, phenotypically or in plasmid content, from those in the inoculum. The basis of this unusual stability pattern is due to the unique characteristics of the $\mathrm{K}$ miniplasmids addressed below and under Discussion.

Figure 3 shows the pattern of pheromoneinducible $\beta$-galactosidase production in cells 


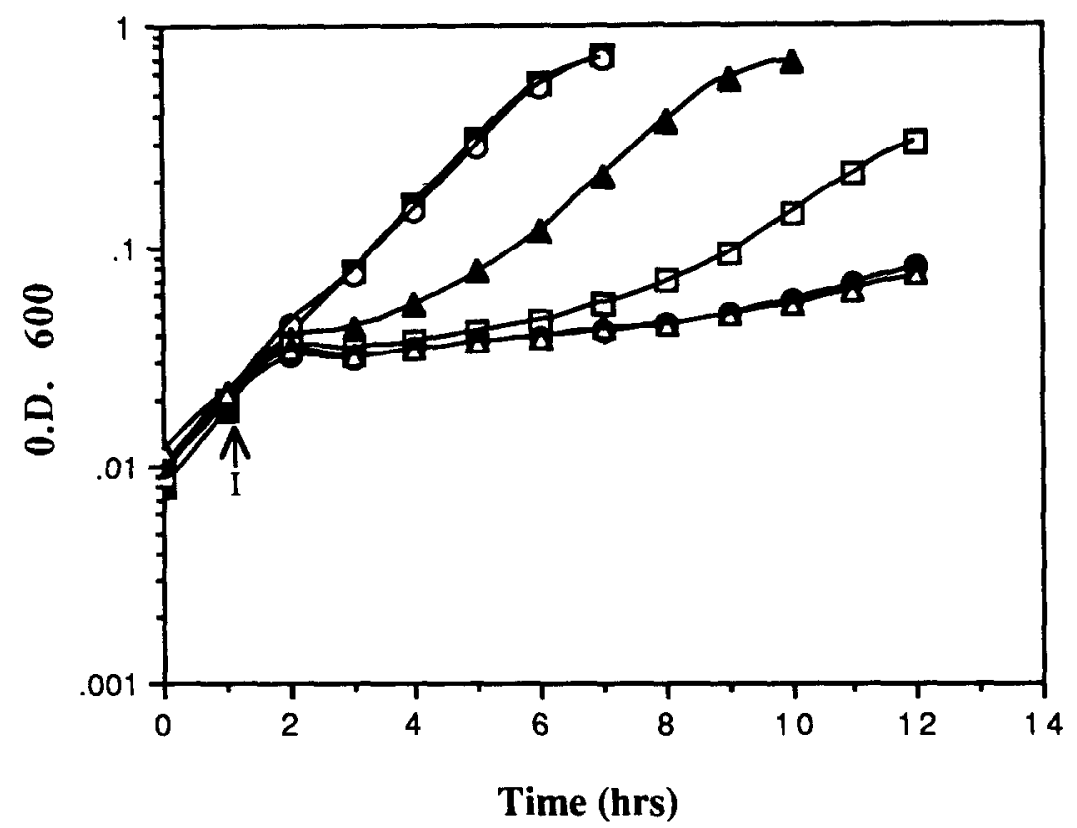

FIG. 4. Pheromone-dependent growth inhibition of pAM2005K-containing cells. OGIX(pAM2005K) was grown overnight in N2GT/Em and then diluted to $1 \%$ in fresh $\mathrm{N} 2 \mathrm{GT} / \mathrm{Em}$. After $1 \mathrm{~h}$ pheromone was added to the indicated concentration: (ద) $0 \mathrm{ng} / \mathrm{ml} ;(O) 0.6 \mathrm{ng} / \mathrm{ml} ;(\Delta) 1.25 \mathrm{ng} / \mathrm{ml} ;(\square) 2.5 \mathrm{ng} / \mathrm{ml} ;(\bullet) 5 \mathrm{ng} /$ $\mathrm{ml} ;(\triangle) 10 \mathrm{ng} / \mathrm{ml}$. The arrow indicates the point at which pheromone was added.

containing the miniplasmids and their parental plasmids. Both pAM2005E and pAM2011E regulated the production of $\beta$-galactosidase from their respective fusions in a manner nearly identical to that observed in the parental plasmids, pAM2005A and pAM2011A, respectively, although activity levels were consistently $10-20 \%$ higher in strains containing the miniplasmids. Regulation of the $\beta$-galactosidase production by pAM2005K and pAM2011K was clearly not normal. The pheromone-inducible promoter appeared to be normally repressed in this plasmid; and, upon exposure to pheromone, some increase in the production of $\beta$-galactosidase was observed. However, $\beta$-galactosidase activity levels reached a maximum at or before pheromone concentrations of $2.5 \mathrm{ng} /$ $\mathrm{ml}$ and were not increased by further addition of pheromone.

Pheromone-Dependent Growth Inhibition of Cells Containing pAM2005K and $p A M 2011 \mathrm{~K}$

Following the 1.5 - $\mathrm{h}$ induction period used to generate the pheromone response curves shown in Fig. 3, it was observed that the culture densities of pAM2005K- and pAM2011Kcontaining cells induced with $>2.5 \mathrm{ng}$ of $\mathrm{cAD} 1$ per milliliter were nearly half those of uninduced cultures. No such difference was observed with either of the $E$ miniplasmids or the parental plasmids. Therefore, it seemed possible that a pheromone-inducible growth inhibition was in some way linked to, or responsible for, the observed failure of the $K$ miniplasmids to normally induce the lac $Z$ fusions.

To test this hypothesis we examined the effects of various pheromone concentrations on pAM2005K-containing cells. Results are shown in Fig. 4. Cultures exposed to pheromone concentrations of greater than $1 \mathrm{ng} / \mathrm{ml}$ showed a detectable decrease in growth rate within 30-40 min of induction. At pheromone concentrations above $2.5 \mathrm{ng} / \mathrm{ml}$, growth inhibition persisted, resulting in a fairly constant growth rate approximately $\frac{1}{10}$ of normal. The generation time in the absence of pheromone is $\approx 1 \mathrm{~h}$ and was increased to greater than 10 $\mathrm{h}$ at pheromone concentrations of 5 and 10 
$\mathrm{ng} / \mathrm{ml}$. At pheromone concentrations below 5 $\mathrm{ng} / \mathrm{ml}$, cultures were observed to recover at a period of time after induction that was dependent on the concentration of inducing pheromone (i.e., the higher the pheromone concentration the greater the lag period before recovery). At these lower pheromone concentrations, recovery was not due to selection of pheromone-resistant mutants since greater than $95 \%$ of isolates from cultures grown to stationary phase could still be inhibited by pheromone. Recovery was also observed after prolonged incubation following induction with pheromone concentrations of $5 \mathrm{ng} / \mathrm{ml}$ and higher, but in this case the majority of isolates from such recovered cultures were pheromone resistant (data not shown). As can be seen from Fig. 4 the effects of pheromone on growth rate are persistent. Even cultures induced with 1.2 $\mathrm{ng} / \mathrm{ml}$ pheromone fail to return to a normal growth rate prior to reaching stationary phase and the higher the pheromone the greater the effect. For example, a maximum growth rate of $80 \mathrm{~min}$ is observed for cultures recovering from induction at $1.2 \mathrm{ng} / \mathrm{ml}$ and $100 \mathrm{~min}$ for cultures recovering from induction at $2.5 \mathrm{ng} /$ $\mathrm{ml}$, compared to $60 \mathrm{~min}$ for uninduced cultures. Similar results were obtained with cultures containing pAM $2011 \mathrm{~K}$, but no significant pheromone-dependent growth inhibition was observed in cultures containing either of the E miniplasmids (data not shown).

Reversibility of inhibition was tested by washing induced pAM2005K-containing cells $1 \mathrm{~h}$ after induction and resuspending in pheromone-free medium. Washed cultures still grew slowly but recovered more quickly than unwashed cultures (data not shown). For example, the generation time of cultures washed and allowed to recover after induction with $2.5 \mathrm{ng}$ of pheromone per milliliter reached 90 $\min 5$ to $9 \mathrm{~h}$ after induction, compared to 100 $\min 7$ to $11 \mathrm{~h}$ aftcr induction for unwashed cultures. One observation that may be connected to the nearly irreversible nature of pheromone inhibition was that pAD1-containing cells are capable of binding and removing exogenous pheromonc from the medium. Thus, if pAM2005A-containing cells were diluted 1:10 from a stationary phase cul- ture, allowed to grow $1 \mathrm{~h}$, and then exposed to $20 \mathrm{ng}$ of pheromone per milliliter within 1 $\mathrm{h}$ after induction the pheromone titer of the culture filtrate dropped from 64 to 2 . Incubation of pheromone with the supernatant of similarly grown cells had no effect on the pheromone titer. In the case of pAM2005Kcontaining cells exposed to $2.5 \mathrm{ng}$ of pheromone per milliliter (titer of four) no pheromone was detectable after $1 \mathrm{~h}$. Therefore, the relative ineffectiveness of washing to reverse inhibition may have been due to the fact that the majority of pheromone was already bound to receptors on the cell surface; washing removed only the residual, unbound pheromone.

Comparable pheromone-dependent growth inhibition occurred in the absence of antibiotic selection. Thus, the generation time of cultures induced with $>10 \mathrm{ng}$ of $\mathrm{CAD} 1$ per milliliter in the absence of erythromycin increased from $48 \mathrm{~min}$ to $>10 \mathrm{~h}$. Cultures induced with 2.5 ng of pheromone per milliliter were initially inhibited and then recovered to a maximal growth rate of 84 min before entering stationary phase. This recovery at $2.5 \mathrm{ng}$ of cAD 1 per milliliter is not due to selection of plasmidfree cells, as $96 \%$ of colonies isolated following recovery remain erythromycin resistant (and pheromone inhibitable). However, when plated on solid media the majority of colonies isolated following recovery at pheromone concentrations above $5 \mathrm{ng} / \mathrm{ml}$ had lost the plasmid. Therefore, pheromone-dependent growth inhibition does not require continued selection for plasmid maintenance.

The effects of pheromone induction on the viability of pAM2005K-containing cells is shown in Fig. 5. Just 20 min after induction with $10 \mathrm{ng}$ of pheromone per milliliter viable counts dropped to $66 \%$ of counts obtained prior to induction. Approximately $1 \mathrm{~h}$ after induction viable counts were reduced by $50 \%$ and then stabilized or increased slightly. In addition, colonies from cultures induced with pheromone took up to a day longer to become visible on plates than colonies from uninduced cultures, again indicating the slow recovery from growth inhibition even after cells are removed from pheromone-containing media. It 


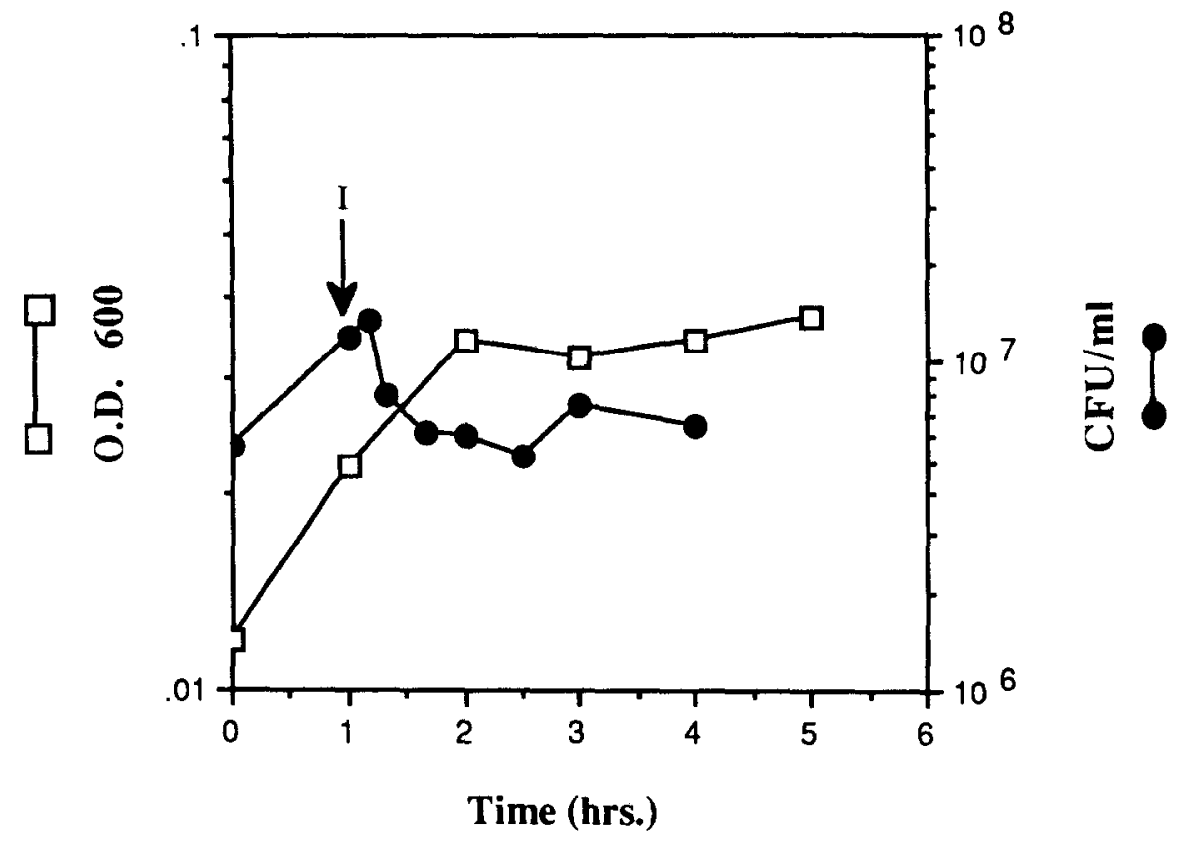

FIG. 5. Pheromone-induced loss of viability. OG1X(pAM2005K) was grown overnight in N2GT/Em, diluted to $1 \%$ in fresh $\mathrm{N} 2 \mathrm{GT} / \mathrm{Em}$, and induced after $1 \mathrm{~h}$ of growth with $10 \mathrm{ng}$ of pheromone per milliliter. Samples were taken periodically and plated on N2GT/EmSm plates to follow viability. Symbols (D) culture optical density at OD 600: (๑) viable counts.

should be noted that the majority of cell death occurred during the period when the optical density of the culture was still increasing, indicating that while cells may increase in mass and actually divide, a significant proportion of new cells is nonviable. This decrease in viability was not accompanied by any visible changes in cell morphology when samples were examined under a phase contrast light microscope.

The effect of pheromone induction on plasmid copy number was also determined. After $1 \mathrm{~h}$ of induction with $40 \mathrm{ng}$ of pheromone per milliliter no detectable change was observed in plasmid copy number.

All of the data presented above indicated that pheromone-dependent growth inhibition was due to the induction of one or more gene products encoded on the $\mathrm{K}$ miniplasmids. In cells containing the E miniplasmids either this gene product is not induced or its effects are moderated via genetic material deleted from the $\mathrm{K}$ miniplasmids. It should be noted here that the Tn917-lac KpnI site used in constructing both $K$ miniplasmids is located within a putative transcription terminator; in addition a transcription termination site at the distal end of the transposon was removed (Shaw and Clewell, 1985). Since the inserted lac $Z$ gene contains no terminator sequences and no other potential terminators have been identified which precede the one interrupted by $K p n I$, it is possible that expression downstream (as well as upstream) of the lac $Z$ gene could account for the observed growth inhibition. To further localize the offending gene we isolated pheromone-resistant revertants of pAM2005K-containing cells either by $\operatorname{Tn} 916$ mutagenesis or by selection of spontaneous mutants on pheromone-containing plates (see Materials and Methods).

Two Tn916 inserts were isolated that resulted in pheromone resistance of plasmidcontaining cells. The location of these inserts is shown in Fig. 2. Although both inserts were mapped to regions upstream of the lac $Z$ gene, both resulted in an inability to induce the lac $Z$ fusion. $K T 24$, the insert closest to the NR5 insert, resulted in total loss of $\beta$-galactosidase expression; activity levels observed were be- 
tween 0.2 and $0.4 \mathrm{MU}$-less than that observed in uninduced pAM2005K. KT16 allowed expression of $\beta$-galactosidase to uninduced levels (2-3 MU) but did not allow significant induction to occur. Therefore, inducible expression both upstream and downstream of the lac $Z$ fusion was affected by these insertions. Furthermore, KT24 is clearly located between the positions of the NR 11 and NR5 inserts. Thus, any putative inhibitory gene product disrupted by KT24 would also be absent in pAM2011K. Since growth of pAM2011K-containing cells was inhibited by pheromone, it is likely that the pheromone resistance of cells containing pAM $2524 \mathrm{KT}$ is due to the effects of the KT24 insert on expression of the region downstream of the lac $Z$ gene.

Results obtained with a spontaneous pheromone-resistant derivative of pAM2005K support this conclusion. Several pheromoneresistant derivatives were isolated that were capable of induction of the lac $Z$ fusion. The majority of these showed no obvious alteration in plasmid DNA, but one derivative was isolated that contained an $\approx 200$-bp deletion within the KpnI-HindIII fragment downstream of the $l a c Z$ and erm genes. The growth rate of strains containing this plasmid, designated pAM2005KR, was not affected by the presence of pheromone even though the promoter controlling lac $Z$ expression is significantly induced. Indeed, as can be seen in Fig. 3 , induction of the lac $Z$ fusion in this mutant occurred to levels higher than those observed in any of the other fusions. The pAM2005KR fusion was also significantly derepressed in the absence of pheromone, producing $\beta$-galactosidase to levels six- to sevenfold higher than those in uninduced pAM2005K.

Since the deletion present in pAM2005KR is located within the region believed to be required for plasmid replication, the plasmid was examined for any changes in maintenance properties. No effect on average plasmid copy number or expression of incompatability was observed. A slight but consistent decrease in plasmid stability was observed. In the absence of selection, pAM $2005 \mathrm{KR}$ was lost at a rate of $0.5-1.0 \%$ per generation. The deletion had no effect on the shutdown of cADl or on the production of iAD1. Thus, the pheromonedependent growth inhibition of pAM2005Kand pAM2011K-containing cells may be due to expression or overexpression of a plasmid stability determinant.

\section{DISCUSSION}

Previous work has identified a cluster of genetic determinants located on the pAD1 $E c o$ RI B fragment that are essential for normal regulation of the pheromone response. Results presented in this report indicate that these genes are not only essential but, at least in the case of the pheromone-inducible $\mathrm{E}$ region product(s), they are also sufficient. Thus, miniplasmids consisting entirely of the pAD1 EcoRI B fragment were (i) capable of normally regulating two different inducible lac $Z$ fusions within the $\mathrm{E}$ region; (ii) able to shut down cAD1 activity; and (iii) able to produce normal amounts of $\mathrm{iAD} 1$. In addition, although it was unable to regulate the fusion normally, it is clear that the smallest miniplasmid isolated, pAM2011K (see Fig. 2), contains determinants sufficient to negatively regulate the pheromone-inducible promoter and sense/ transduce the pheromone signal. Cells containing pAM2011K also shut down cAD1 activity and produce $\mathrm{A} A \mathrm{D} 1$. It should be noted that these results do not rule out the possible involvement of host (chromosomally encoded) factors in controlling the pheromone response. Also, whereas the E region is believed to encode a positive regulator(s), it is possible that additional "regulators" may be necessary for induction of aggregation and transfer functions.

Results indicate that sufficient information for normal plasmid maintenance is also present on the miniplasmids. Thus, miniplasmids were maintained at a normal copy number and expressed normal incompatability characteristics. Although stability of the $\mathrm{K}$ miniplasmids seemed variable from experiment to experiment, the fact that pAM $2005 \mathrm{~K}$ was stably maintained for 40 to 100 generations in some cases indicates that information sufficient for stable maintenance is also present. 
Variability was most likely due to exaggeration of the rate of loss due to the inhibitory effects of pheromone produced by plasmid-free segregants on the remaining plasmid-containing cells. The smallest miniplasmid, pAM2011K, is approximately $14.8 \mathrm{~kb}, 4.8 \mathrm{~kb}$ of which represents the remaining Tn917-lac DNA. Of the remaining $10 \mathrm{~kb}$ of plasmid DNA, approximately $7 \mathrm{~kb}$ has been previously identified as important for the pheromone response. Assuming that there are no overlapping functions, this leaves approximately $3 \mathrm{~kb}$ of plasmid DNA for carrying out the required maintenance functions.

The $\mathrm{K}$ miniplasmids failed to induce their respective fusions to levcls observed in either the parental or the E miniplasmids, presumably because growth of cells containing these plasmids was inhibited under the conditions used to induce the cells. The dose-related response to pheromone and the isolation of Tn916 inserts in pAM2005K which interfere with both pheromone-related growth inhibition and production of $\beta$-galactosidase indicates that growth inhibition is related to transcription initiated at the promoter(s) controlling transcription of the NR5 and NR11 fusions. The positions of the Tn916 inserts and the isolation of a spontaneous pheromone-resistant mutant containing an $\approx 200$-bp deletion in the area suspected of encoding replication functions suggest that inhibition may be due to transcriptional readthrough from an E region promoter into the rep region. This is possible because the Tn917-lac remnant present in the $\mathrm{K}$ miniplasmids does not have a functional transcription terminator. Because growth inhibition occurs in the absence of selection for plasmid maintenance it is unlikely that it is due to transcriptional interference with plasmid replication alone. In the absence of selection such interference might lead to the rapid accumulation of plasmid-free segregants but with little or no effect on culture growth rates. However, at least three low copy number plasmids, F, R 100, and R1, have been found to encode determinants ( $c c d$, pem, and $h o k$, respectively) which function to enhance plasmid stability by killing plasmid-free segregants (Hiraga et al., 1986; Tsuchimoto et al.,
1988; Gerdes et al., 1986). If such a system were operative in pAD1, transcriptional interference with pAM2005K plasmid replication could lead to inhibition of growth indirectly by giving rise to plasmid-free segregants which are then killed. Alternatively, if such a gene were fused directly to the pheromoneinduced transcript, overproduction of its gene product could lead to cell death, as has been observed when the R1 hok gene is overproduced (Gerdes et al., 1986). The observed decrease in viability of pAM2005K-containing cells following pheromone induction and the slight but consistent decrease in plasmid stability of the spontaneous pheromone-resistant mutant pAM2005KR are consistent with this hypothesis. In addition, both $c c d$ and pem are located near the respective plasmid replication regions, as is the deletion in pAM2005KR. Alternatively, overexpression of some other replication function could lead to growth inhibition. Since there is no significant increase in plasmid copy number in induced pAM2005K-containing cells, it is unlikely that inhibition is due to runaway plasmid replication.

One may wonder why erythromycin itself does not induce growth inhibition since the erm gene is located downstream of the lac $Z$ gene and resistance is known to be inducible. However, the Tn917 erm gene is one of a family of inducible erythromycin resistance genes that are regulated by translational attenuation (Gryczan et al., 1980; Horinouchi and Weisblum, 1980). Thus, erythromycin induction of the erm gene affects only translation of its own gene product and would not be expected to increase the production of other gene products with their own ribosome binding sites encoded on the same transcript.

Three intriguing aspects of the pheromonedependent growth inhibition phenomenon may have relevance to the pheromone response. First, induced cells were able to recover from pheromone inhibition. At low concentrations of pheromone this recovery was not due to selection of either plasmid-free or pheromone-resistant cells. The gradual nature of recovery indicates that it may not be due to outgrowth of uninduced, and therefore un- 
inhibited, cells. One possible explanation is that induced cells have a mechanism for terminating the pheromone signal, either by inactivation of the pheromone itself or by modifying the receptor or signal transducer in some unknown way. The observed pheromone binding may also be important for moderating the pheromone signal. Second, the effects of the KT24 and KT16 Tn916 inserts have implications regarding the organization and regulation of the $\mathrm{E}$ region gene products. The KT24 insert resulted in the virtual elimination of transcription of the $l a c Z$ fusion, implying that this insert is located between the lac $Z$ gene and the pheromone-inducible promoter. The KT16 insert, however, allowed transcription of the lac $Z$ gene at uninduced levels but did not allow pheromone induction of the fusion. Outward reading promoter-like sequences have been observed in the right end of Tn 916 (Clewell et al., 1988), but in pAM2516KT the transposon is inserted in the wrong orientation for these putative promoters to affect lac $Z$ expression. Therefore, the KT16 insert may be located in a regulatory site or gene required for induction. Alternatively, the left end of Tn916 may have an as yet unidentified promoter. Finally, the deletion present in plasmid pAM2005KR not only resulted in pheromone resistance but also affected production of $\beta$ galactosidase from the inducible fusion. Higher levels of expression were observed in the absence of pheromone as well as following pheromone induction. No significant increase in plasmid copy number was observed, making it unlikely that a related increase in gene dosage could account for the observed six- to sevenfold increase in uninduced levels of $\beta$-galactosidase production. This is the first indication that genetic information encoded in this region can effect the pheromone response and may indicate a link between plasmid replication and phcromone induction. Further investigation of this and other spontaneous pheromone-resistant mutants of the $\mathrm{K}$ miniplasmids may be useful in establishing such a link.

In conclusion, in this report we describe the isolation of a number of pAD1 miniplasmids which encode sufficient information to regu- late a pheromone-inducible gene and to control plasmid replication. These plasmids will prove very useful for further studies on the control of the pheromone response and on the examination of the replication properties of plasmid pAD1.

\section{ACKNOWLEDGMENTS}

We thank L. Pontius, M. Sulavik, and F. An for helpful discussions. This study was supported by Public Health Service Grants GM33956 and DE02731 from the National Institutes of Health.

\section{REFERENCES}

Clewell, D. B., AN, F. Y., White, B. A., AND GAWronBuRKE, C. (1985). Streptococcus faecalis sex pheromone (cAM373) also produced by Staphylococcus aureus and identification of a conjugative transposon $(\operatorname{Tn} 916) . J$. Bacteriol. 162, 1212-1220.

Clewell, D. B., AND Brown, B. L. (1980). Sex pheromone $\mathrm{CAD} 1$ in Streptococcus faecalis. Induction of a function related to plasmid transfer. J. Bacteriol. 143, 1063-1065

Clewell, D. B., Ehrenfeld, E. E., Kessler, R. E., IKE, Y., Franke, A. E., Madion, M., ShaW, J. H., Wirth, R., AN, F., MORI, M., KITADa, C., FujINo, M., AND SuzUKI, A. (1986). Sex-pheromone systems in Streptococcus faecalis. "Banbury Report No. 24. Antibiotic Resistance Genes: Ecology, Transfer, and Expression," pp. 131-142. Cold Spring Harbor Laboratory, Cold Spring Harbor, NY.

Clewell, D. B., Flannagan, S. E., Ike, Y., Jones, J. M., AND GAWron-Burke, C. (1988). Sequencc analysis of termini of conjugative transposon $\operatorname{Tn} 916 . J$. Bacteriol. 170, 3046-3052.

Clewell, D. B., TOMICh, P. K., GaWron-Burke, M. C., Franke, A. E., YaGi, Y., AND AN, F. Y. (1982). Mapping of Streptococcus faecalis plasmids $\mathrm{pAD} 1$ and $\mathrm{pAD} 2$ and studies relating to transposition of $\mathrm{Tn} 917$. J. Bacteriol. 152, 1220-1230.

Clewell, D. B., YaGi, Y., DUNNY, G. M., AND SCHUltZ, S. K. (1974). Characterization of three plasmid deoxyribonucleic acid molecules in a strain of Streptococcus faecalis: Identification of a plasmid determining erythromycin resistance. $J$. Bacteriol. 117, 283-289.

Dunny, G. M., Brown, B. L., AND Clewell, D. B. (1978). Induced cell aggregation and mating in Streptococcus faecalis. Evidence for a bacterial sex pheromone. Proc. Natl. Acad. Sci. USA 75, 3470-3483.

Dunny, G. M., Craig, R. A., Carron, R. L., AND Clewell, D. B. (1979). Plasmid transfer in Streptococcus faecalis: Production of multiple sex pheromones by recipients. Plasmid 2, 454-465.

DunNy, G. M., Zimmerman, D. L., AND M. L. TORTORELLO. (1985). Induction of surface exclusion (entry exclusion) by Streptococcus faecalis sex pheromones: 
Use of monoclonal antibodies to identify an inducible surface antigen involved in the exclusion process. Proc. Natl. Acad. Sci. USA 82, 8582-8586.

EHRENFELD, E. E., AND CLEWELL, D. B. (1987). Transfer functions of the Streptococcus faecalis plasmid pAD1: Organization of plasmid DNA encoding response to sex pheromone. J. Bacteriol. 169, 3473-3481.

EHRENFELD, E. E., KesSLER, R. E., AND CLEWELL, D. B. (1986). Identification of pheromone-induced surface proteins in Streptococcus faecalis and evidence of a role for lipoteichoic acid in formation of mating aggregates. J. Bacteriol. 168, 6-12.

Gawron-Burke, C., AND Clewell, D. B. (1982). A transposon in Streptococcus faecalis with fertility properties. Nature (London) 300, 281-284.

Gerdes, K., RASMUSSEN, P. B., AND MOLIN, S. (1986). Unique type of plasmid maintenance function: Postsegregational killing of plasmid-free cells. Proc. Natl. Acad. Sci. USA 83, 3116-3120.

Gryczan, T. J., Grandi, G., Hahn, J., Grandi, R., AND DUBNAU, D. (1980). Conformational alteration of InRNA structure and the post-transcriptional regulation of erythromycin-induced drug resistance. Nucleic Acids Res. 8, 6081-6097.

Hiraga, S., , AfFe, A., OGURA, T., Mori, H., AND TaKaHASHI, H. (1986). F plasmid $c c d$ mechanism in Escherichia coli. J. Bacteriol. 166, 100-104.

HORINOUCHI, S., AND WeISBlum, B. (1980). Post-transcriptional modification of mRNA conformation that regulates erythromycin-induced resistance. Proc. Natl. Acad. Sci. USA 77, 7079-7083.

IKE, Y., AND CLEWELL, D. B. (1984). Genetic analysis of the pAD1 pheromone response in Streptococcus faecalis, using transposon $\mathrm{Tn} 917$ as an insertional mutagen. $J$. Bacteriol. 158, 777-783.

IKe, Y., Craig, R. C., White, B. A., YaGi, Y., AND ClewELL, D. B. (1983). Modification of Streptococcus faecalis sex pheromones after acquisition of plasmid DNA. Proc Natl. Acad. Sci USA 80, 5369-5373.

IKE, Y., Hashimoto, H., AND Clewell, D. B. (1984). Hemolysin of Streptococcus faecalis subspecies zymogenes contributes to virulence in mice. Infect. Immun. 45, 528-530.

IKE, Y., HaShimoto, H., AND Clewell, D. B. (1987). High incidence of hemolysin production by Enterococcus (Streptococcus) faecalis strains associated with human parenteral infections. J. Clin. Microbiol. 25, 15241528.

MiLLER, J. H. (1972). "Experiments in Molecular Genetics." Cold Spring Harbor Laboratory, Cold Spring Harbor, NY.

Mori, M., Isogai, A., Sakagami, Y., Fujino, M., KITADA, C., Clewell, D. B., AND SuzuKI, A. (1986). Isolation and structure of Streptococcus faecalis sex pheromone inhibitor, $\mathrm{iAD1}$, that is excreted by donor strains harboring plasmid pAD1. Agric. Biol. Chem. 50, 539-541.

MORI, M., SAKaGami, Y., ISHiI, Y., IsOGaI, A., KitADA, FuJino, M., ADSIT, J. C., DUNNY, G. M., AND SuZukI, A. (1988). Structure of cCF10, a peptide sex pheromone which induces conjugative transfer of the Streptococcus faecalis tetracycline resistance plasmid, pCF10. J. Biol. Chem. 263, 14,574-14,578.

Mori, M., Sakagami, Y., Narita, M., Isogal, A., Fujino, M., Kitada, C., Craig, R. A., Clewell, D. B., AND SUZUKI, A. (1984). Isolation and structure of the bacterial sex pheromone, cAD1, that induces plasmid transfer in Streptococcus faecalis. FEBS Lett. 178, 97100.

PERKINS, J. B., AND Youngman, P. J. (1986). Construction and properties of $\operatorname{Tn} 917-l a c$, a transposon derivative that mediates transcriptional gene fusions in Bacillus subtilis. Proc. Natl. Acad. Sci. USA 83, 140-144.

Shaw, J., H., AND Clewell, D. B. (1985). Complete nucleotide sequence of macrolide-lincosamide-streptogramin B-resistance transposon Tn917 in Streptococcus faecalis. J. Bacteriol. 164, 782-796.

SuzuKI, A., Mori, M., SaKaGami, Y., Isogal, A., Fujino, M., Kitada, C., Craig, R. A., and Clewell, D. B. (1984). Isolation and structure of bacterial sex pheromone cPD1. Science 226, 849-850.

TOMiCh, P. K., AN, F. Y., DAMLE, S. P., AND Clewell, D. B. (1979). Plasmid-related transmissability and multiple drug resistance in Streptococcus faecalis subspecies zymogenes strain DS16. Antimicrob. Agents Chemother. $15,828-830$.

TORTORELlO, M. L., AND DUNNY, G. M. (1985). Identification of multiple surface antigens associated with the sex pheromone response of Streptococcus faecalis. J. Bacteriol. 162, 131-137.

Tsuchimoto, S., OHTSUBO, H., AND OHTSUBo, E. (1988). Two genes, pemK and pemI, responsible for stable maintenance of resistance plasmid R100. J. Bacteriol. 170, 1461-1466.

Weaver, K. E., AND D. B. Clewell. (1988). Regulation of the pAD1 sex pheromone response in Enterococcus faecalis: Construction and characterization of lacZ transcriptional fusions in a key control region of the plasmid. J. Bacteriol. 170, 4343-4352.

WIRTH, R., AN, F. Y., AND CLEWELL, D. B. (1986). Highly efficient protoplast transformation system for Streptococcus faecalis and a new Escherichia coli-S. faecalis shuttle vector. J. Bacteriol. 165, 831-836.

YAGI, Y., Kessler, R. E., Shaw, J. H., Lopatin, D. E., AN, F. Y., AND CleWELL, D. B. (1983). Plasmid content of Streptococcus faecalis strain 39-5 and identification of a pheromone (CPD1)-induced surface antigen. J. Gen. Microbiol. 129, 1207-1215.

Communicated by Francis L. Macrina 